ledge of its presence and, equally important, its absence, from estuarine mussels of other parts of the country would be invaluable, and I would be very grateful for information on this point.

The parasite should be very useful for teaching and other purposes, for the ease with which living Mytilus can be sent through the post means that, probably for the first time, a living parasitic copepod will be easily available to inland laboratories ; mussels from the Blyth may be obtained from the Dove Marine Laboratory, Cullercoats, Northumberland.

Department of Zoology, C. Ellenby King's College,

University of Durham,

Newcastle-upon-Tyne. March 11.

1 Steuer, A., Zool. Anz., 25, 635 (1902).

2 For references, see Monod, Th., and Dollfus, R. Ph., Ann. Parasit. Hum. Comp., 10, 129 (1932).

${ }^{3}$ Caspers, H., Zool. Anz., 126, 161 (1939).

\section{Copper in Diatoms}

Work undertaken in this Laboratory suggests that certain species of diatoms, which are the normal constituents of the slime film which forms upon a submerged surface in marine waters, contain copper, far in excess of the amount usually considered lethal for unicellular Algæ. (Half to one part per million is usually sufficient to remove algal growths from reservoirs.) Large colonies of marine diatoms were gathered freshly during the spring maximum of 1946 , from a raft located in Chichester Harbour. Sixteen samples were examined: Nos. 1-12 inclusive were species which live in frondose colonies of mucous filaments, 5-10 cm. in length ; samples Nos. 13-16 inclusive were species which grow either upon mucous stalks or embedded within a flat film.

After collection, the material was examined carefully and sorted into monotypic samples, care being taken to remove any contaminants such as filamentous seaweeds. The selected material was washed several times with filtered sea water, and examined for copper, using sodium diethyldithiocarbamate as an indicator. All samples gave a positive reaction, while samples 3-11 were submitted further to a quantitative estimation. The quantitative determination of copper was effected by the use of the absorptiometer method described by Haywood and Wood ${ }^{1}$, with some special modifications. The selected material was washed free from salt and dried in a vacuum desiccator for 48 hours. Weighed portions of $0.5 \mathrm{gm}$. were wet-ashed; ammonium citrate was added in order to inhibit any iron that might be present, and strong solution of ammonia added, sufficient to produce an alkaline reaction. The mixture was then filtered to remove the siliceous skeletons' of the diatoms, and the volume adjusted. Sodium diethyldithiocarbamate was added to a measured quantity of the mixture, which was allowed to stand for 15 minutes. The copper complex developed a yellow coloration, which was extracted by shaking with carbon tetrachloride, and estimated on a Hilger 'Spekker' absorptiometer.

The results showed that the diatoms contained from 31 to 164 parts per million of copper (weight/ weight). The copper content of the sea water in which the diatoms lived was $0.007 \mathrm{mgm}$. per litre ( 7 parts per thousand million). It is not known in which form the copper is contained, but it is likely that it forms either an additive compound with the protein or alginin molecule within the diatom cell, and is thrown down as a coagulate or precipitate, or that it plays a functional part in the chromatophores.

Evidence from work upon cultures of diatoms without their siliceous frustule ${ }^{2}$ indicates that the organisms can tolerate copper far in excess of that allowed by the range of solubility of copper in sea water of $p H \quad 7 \cdot 92-8 \cdot 2$, which probably does not exceed 0.5 parts per million. It appears that the diatom forming so large a part of the slime which develops upon an underwater surface may be considered as a potential reservoir of copper, and in this way may play an important part in preventing the settlement of other and more sensitive fouling organisms.

Acknowledgment is made to the Board of Admiralty for permission to publish the foregoing work, which forms part of a general investigation in progress in this Laboratory on the anti-fouling problem relating to ships.

N. TNGRam HendeY

Admiralty Central Metallurgical Laboratory, Emsworth House, Emsworth, Hants. March 8.

I Haywood, F. W., and Wood, A. A. R., "Metallurgical Analysis by Means of the Spekker Photo-electric Absorptiometer" (London, 1944).

${ }^{2}$ Hendey, N. Ingram, Nature, 158, 588 (1946).

\section{The New Lava from Hekla}

ON April 10 I received from Dr. Jóhannes Áskelsson of Reykjavik a specimen of the new lava from Hekla. Dr. Áskelsson states that the eruption began on March 29 at 7 a.m. (Icelandic time), and several lava streams began to flow in different directions. The specimen he sent was taken from the surface of the moving lava of a stream flowing east from the northern end of the Hekla ridge. It is a typical aa or block lava.

The rock is a dead black, highly slaggy basalt in which a few fresh white feldspars are entangled. In thin section the bulk of the rock turns out to be a brownish-black glass holding numerous swallowtailed feldspar microlites, a few micro-phenocrysts of labradorite $\left(A b_{1} A n_{1}\right)$, and still fewer of pyroxene and olivine.

This lava is identical with previous flows from Hekla, as I have ascertained by direct comparison with material collected by Sir George Steuart Mackenzie in $1810^{1}$, which is preserved in the Hunterian Museum of the University of Glasgow. It is also identical with the Selsundhraun (hraun, Icel.=lava), a Recent flow $10 \mathrm{~km}$. south-west of Hekla, of which I possess an unpublished analysis. This analysis agrees very closely with $\mathrm{H}$. S. Washington's analysis of a Hekla lava from Nafrholt ${ }^{2}$, and with Recent lavas from the Vatnajökull region ${ }^{3}$. All these magmas are slightly over-saturated with silica notwithstanding the early crystallization of a little olivine. It may therefore be concluded that the Recent basalt lavas of Iceland are very uniform in composition, and that there has been little or no change in that respect during the historical period.

Geological Dept.,

G. W. TyrReLI

University of Glasgow. April 22.

1 "Travels in Iceland during the Summer of 1810 " (Edinburgh, 1811). a Bull. Geol. Soc. Amer., 33, 783 (1922).

${ }^{3}$ Askelsson, J., Soc. Scient. Islandica, 18, 55 (I936). 